\title{
THE APPLICATION OF SAFINDA METHOD IN TRANSLATION LEARNING AL-QUR'AN IN STUDENTS IN FATTAHUL MULUK PAPUA
}

\author{
Syaiful Muhyidin ${ }^{1}$ \\ Achmad Abubakar ${ }^{2}$ \\ M. Sabir Umar ${ }^{3}$ \\ Munir $^{4}$
}

Post Graduate Program of Alauddin State Islamic University Makassar, Indonesia ${ }^{1}$ Lecture at The Faculty of Tarbiyah and Teacher Training Alauddin State Islamic University Makassar, Indonesia ${ }^{2,3,4}$

achmad.abubakar@uin-alauddin.ac.id ${ }^{2}$

\begin{abstract}
This paper elaborates on the application of the Safinda method in learning the translation of al-Quran for students at IAIN Fattahul Muluk Papua. This type is qualitative research, the research approach is a phenomenological perspective and a descriptive analysis approach, and data sources are primary data and secondary data, data collection techniques through observation, interviews, and documentation. The research instrument, namely, the researcher as a key instrument, observation guide, interview guide and documentation reference, data processing and analysis techniques namely data reduction, data presentation, conclusion and verification, data validity testing, namely triangulation techniques, checking the correctness of the information, discussing and consulting data, and extending research time. The results of the study found that the application of the Safinda method in learning the translation of alQuran to students at IAIN Fattahul Muluk Papua was carried out by (a) paying attention to class management which included classroom arrangement and student management before entering preliminary activities; (b) in the introductory activity, the lecturer starts learning effectively and pleasantly by providing motivation to students; (c) the core activities are carried out through reading activities, aural-oral activities, and memorizing activities are all carried out classically and individually, namely the lecturer reads word for word followed by students, lecturers and students read word for word, students read word for word, the lecturer interprets it, the students interpret all the verses that have been read together, the students read one by one, then the lecturer gives the opportunity to students who do not understand to ask questions, and finally the lecturer explains all the verses that have been studied together.
\end{abstract}

Keywords: Safinda Method; Learning Al-Qur'an Translation

\section{INTRODUCTION}

Historically, learning al-Quran in Indonesia grew and developed in tandem with the spread of Islam. Wherever there are Muslims, it is certain that a mosque will be 
built ${ }^{1}$ which functions as a place of worship, apart from being a place of worship as well as a center for recitation, both for children, adolescents, adults and the elderly, as well as general recitation. ${ }^{2}$

Today, along with the rapid growth of the number of tertiary institutions, each higher education institution is competing to attract prospective students by improving the quality in terms of its curriculum and various aspects, especially for universities with the label of Islamic universities. Students need to be equipped with knowledge and understanding of al-Quran which is the main source of Islamic teachings.

A fundamental need for Muslims, namely the importance of understanding alQuran, especially in the IAIN Fattahul Muluk Papua environment, because studying alQuran is an important part of a Muslim's evidence to believe in the truth of al-Quran and believe in it.

Studying and understanding the Qur'an is an obligation that must be carried out for every Muslim, as well as teaching it. Learning al-Quran can be divided into several levels, namely: learning to read it fluently and well according to the rules that apply in reading it (qira'at) and the rules of reading it (tajwid). Second, namely learning in terms of the meaning and purpose contained therein. The latter is learning to memorize (tahfiz) by heart, as was done by the companions at the time of the Prophet until now.

Translating al-Quran and knowing its contents is a very easy thing if we can know the right method to be used, including supporting it so that it is successful in training or learning there needs to be the right media. ${ }^{3}$ Therefore, there are several problems faced by the translators of the Qur'an, starting from developing interest, creating a qur'ani environment, time efficiency, to the method of translating al-Quran which is implemented for the purpose of understanding al-Qur'an. -Qur'an really accomplished.

The Safinda method of translating the al-Qur'an training program is a method of learning the translation of al-Quran as well as additional material on the grammar directly from Arabic in a simple, easy and practical way. This program is deliberately designed for all Muslims who have never studied Arabic or have never studied at a pesantren.

The Safinda method can be accepted in society, especially among students of IAIN Fattahul Muluk Papua, as an appropriate method for learning to understand alQuran, especially Muslims who have never studied Arabic or attended Islamic boarding schools.

In the training process, especially the translation of al-Quran, a method is far more important than material. That is the urgency of the method in the training process. A training process can be said to be less successful if the process does not use methods. Because the method occupies the most important position after the goal and a series of other components, namely objectives, methods, materials, strategies, media and evaluation. ${ }^{4}$

\footnotetext{
${ }^{1}$ Masjid adalah tempat untuk salat berjamaah lima waktu dan tempat untuk melakukan kajiankajian Islam, namun tidak dipergunakan untuk jamaah salat Jum'at, dan biasanya tempat untuk melakukan salat Jum' at namanya masjid.

${ }^{2}$ Kafrawi, Pembaharuan Sistem Pendidikan Pondok Pesantren (Jakarta: Cemara Indah, 1978), h.17.

${ }^{3}$ Arif S. Sadiman dkk, Media Pendidikan (Jakarta: Grafindo Persada, 2006), h.32.

${ }^{4}$ Armai Arief, Pengantar Ilmu dan Metodologi Pendidikan Islam (Jakarta: Ciputat Press, 2002), h.109.
} 
A method is said to be perfect if it can deliver to the intended goal. Likewise in translating al-Quran, a good method will have a strong influence on the process of translating al-Quran, so that it can be maximized in training in translating al-Quran.

The training program translates al-Quran Safinda method uses props that lecturers are no longer difficult to convey the material and shorten the time for not longer writes material on the board wrote. Because knowing the translation of alQuran is not impossible or impossible and is a form of worship that is highly recommended. For Muslims who want to do it Allah swt., has guaranteed the ease of memorizing al-Quran, including its translation.

This paper elaborates on the application of the Safinda method in learning the translation of al-Quran for students at IAIN Fattahul Muluk Papua.

\section{THEORETICAL STUDY}

The method of translating al-Quran is the most precise and fast way to express the meaning of kalam (speech) contained in a language with another kalam and by using another language (not the first language), complete with all its meanings and meanings. -the meaning of al-Quran. researcher;

Several methods of learning the translation of al-Quran obtained by the

\section{a. The Manhaji Method}

The Surabaya Manhaji method, the Manhaji method was developed by M. Anas Adnan. The approach to learning the Al-Qur'an translation of the Manhaji method uses classical and individual learning approaches together in one class, and the number of participants in this learning in one class is limited to a maximum of 15 people. Classes are grouped based on age and educational background. ${ }^{5}$

The learning method for translating the Manhaji al-Qur'an was developed by M. Anas Adnan. With the premise that learning the language of al-Quran is "easy" for the following reasons:

1. First, the word "difficult" can happen if you have tried many times but you can't, even though only a few verses have been tried, and it's impossible to understand just one verse until you try several times.

2. Second, it is not the language of the Qur'an that is difficult, but the Indonesian vocabulary is not as complete as Arabic, many Arabic words are absorbed into Indonesian.

3. Third, it is not certain that the words in Indonesian can be used to interpret the desired language in the language of al-Quran.

4. Fourth, because of the factor of educators and the methods used were insufficient or inappropriate. ${ }^{6}$

If students are good at reading, they don't need to be guided anymore.

${ }^{5}$ M.AnasAdnan,MemahamiAl-Qur'andenganMetodeManhaji (Surabaya: Pendidikan dan Pengembangan al-Qur'an(PPQ),2008), h. xii.

${ }^{6}$ M.AnasAdnan,MemahamiAl-Qur'andenganMetodeManhaji, h.xii. 
1. The stage of interpreting word for word

Ustadz interprets it to word for word, students imitate it classically, up to one verse, then students are allowed to repeat it in turn. If the ability of students is known, then the smartest one is given the opportunity first, and the one with the lowest absorption is given the last chance.

2. The stage of understanding the meaning of the verse

After that student are invited to learn to understand the meaning and meaning of the verse. Because maybe they can interpret it word for word, but after being asked to compose it in one verse they do not understand or misunderstand. So if necessary, ustadz explains his Asbab al-Nuzul. This method lasts until a face-to-face study material is completed.

\section{Synthetic Stage}

After understanding each verse, proceed with linking the verse to the previous verse. If there is a connection, then the participants will get an understanding of the linkage of the verses, otherwise, if not, the participants will understand the existence of each verse.

\section{Evaluation Phase}

Ustadz evaluates classically or individually, sporadically and spontaneously, from the beginning to the end of the face-to-face material. And so on, this technique is applied according to the level, which each level needs to complete one juz. follows:

The stages of learning to translate the Qur'an from the Manhaji Method are as

a) First, the basic level

Students understand the meaning of words and their changes, for words that can change, with details:

1) The first half of juz 1 (starting from verse 1s.d. 66) interprets word for word and understands its real meaning, figurative or parable meaning and so on.

2) Half Juz 1 second part (starting from verse 67 to 141) Interpreting word for word, plus introducing the types of sentences, namely Isim, Fi'il ( Madhi, Mudhari and Amr) and letters. After reaching half of this level it is added with the introduction of the form of transformation from Madhi to Mudhari 'and to Amar and vice versa.

In this level, students are expected to have mastered one juz, which consists of approximately 3666 words, and to be able to distinguish the types of existing sentences, how to interpret them, and how to determine changes in the verb (Fi'il).

b) Second, intermediate level

Students are still learning the techniques of interpreting the sentence, plus how to change it, with details: 
1) Half juz 2 the first part (starting from verse 143 to 2013) means that word for word is no longer necessary, only the text of the verse is still chopped up word by word, then developed by recognizing Fi'il Jamid and Mutasharif and how to change it.

2) Half Juz II, second part interpreting words, and getting to know Sahih and Mu'tal and how to change them. At this level, learners learn to conjugate all kinds ficil, follow dhamir her.

c) Third, Top Level

Students begin to recognize sentence structure, the details are as follows:

1) $1 / 3$ Juz 3 the first part: interpreting words by recognizing which is Madni and which is Mu'rab, both Isim and Fi'il .

2) $1 / 3 \mathrm{Juz} 3$ second part: interpret the words plus introduce the easy parts of the sentence.

3) $1 / 3$ Juz 3 third part: Interpreting words and recognizing the Fadhlah/Takmilah part. At this level, students can interpret word for word, then get to know various kinds of sentence structure (number).

d) Fourth, High Level

At this level it reaches Juz IV, with material emphasis on the application of Balaghah Science, with the following details:

1) Understanding of al-Ma'ani and al-Bayan Sciences

2) Understanding Science of al-Badi'

The learning method for translating the Manhaji al-Qur'an was developed by M. Anas Adnan. With the premise that learning the language of al-Quran is "easy".

\section{b. Tamyiz method}

The West Java Tamyiz method, the Tamyiz method uses worksheets and basic theories of nerves and nahu and needs to be encouraged to read and memorize alQu'ran. Tamyiz method using work-books (work sheed) on the formulation of the foundations of quantum theory of grammar and saraf that fall into the category of Arabic For specifik Purpose (ASP). The target is very simple, since childhood SD / MI children are usually educated to read, translate and write or imla 'al-Quran and the yellow book. The Tamyiz method shahih test has been conducted openly by Dr. Akhsin Sakho Muhammad al-Hafiz (Rector of the Jakarta Institute of Al-Qur'an Science and Secretary of the Lajnah Pentashih Qur'an, Ministry of Religion of the Republic of Indonesia in Indramayu. ${ }^{7}$

The Tamyiz method is a method of learning the basic theory of NahwuShorof related to the translation of Arabic texts based on al-Quran, using the book Tamyiz Abaza MM., And Kawkaban Dictionary written by Dr. Akhsin Sakho Muhammad and Abaza, MM. This method is based on the belief that learning al-Quran is "easy" for the following reasons:

\footnotetext{
${ }^{7}$ Abaza, Tamyiz PintarTarjamahQur'andan KitabKuning(Jakarta:TamyizPublising,2013), h. 7.
} 
1. Allah guarantees that al-Quran is easy to learn and that Allah teaches alQuran to those who want to learn it.

2. Arabic has more than 30,000 mufradats/vocabularies, 2,065 words consisting of 1,676 mustaqs and 389 jamids.

3. The above vocabulary is repeated in al-Quran 77,865 times, so that memorizing the translation of al-Quran becomes easier. ${ }^{8}$

The stages and techniques in learning the Al-Qur'an translation of the Tamyiz method are as follows:

First, Tamyiz I (24 hours of study), which aims to make students good at translating al-Quran with the help of the Kawkaban dictionary, which is a special dictionary to help the Tamyiz book. In Tamyiz 1, the key is that students are good at reading the Qur'an intermittently, clever in tashrif and dlami, and clever in mujarrad (opening a dictionary).

Second, Tamyiz 2 (100 hours of study), which aims to make the students good at translating the yellow book. Tamyiz 2 increases at the stage of students being good at reading dotted yellow books, smart I'rab, awamil, shibhu al-total, the number of fi'liyah and ibtidaiyah.

Third, Tamyiz 3 aims to make students good at translating and teaching alQuran and the yellow book. In Tamyiz 3 this is the last tamyiz, the target is students who are good at nahwu and shorof theories who are only easy to understand by understanding their meaning.

The principles of teaching and learning in the tamyiz method are as follows:

1. The principle of how to teach

a) Teaching with the language of the heart Teaching can be by mouth can be with the heart, and Allah according to al-Quran to the human heart.

b) Teaching by obeying the stages.

2. Principles of learning

a) LADUNI (Ilate Kudu Muni)

Students learn by raising their voice as a way to optimize the use of the potential of the left brain and right brain in a balanced manner, coupled with integrative repetition techniques as a way to optimize the potential of the subconscious brain (qolbun/shudur) so that learning outcomes will be more optimal.

b) SENTOT (Santri TOT)

The student learning model is a model of ustadz who is teaching or explaining to students, so that students can automatically teach to others.

3. The principle of how to evaluate teaching and learning

a) Easy

The learning process must be felt easy by the students, if there are students who have difficulties, it means that the teaching method is less effective.

${ }^{8}$ Abaza, Tamyiz Pintar Tarjamah Qur'an dan Kitab Kuning,h. 7 
b) The final impression of the students is good

"If that's the only way, I can also teach Tamyiz".

\section{c. Tikror Method}

The Bandung Tikror method, in language, means repetition, which is a method of learning to translate with a system of repeating a lot. The more repeats, the faster it can be. The method was invented by Abu Nibras (Muhammad Ainul Yaqin) who came from Semarang, based on his experience teaching (LPPTQ) 40 hours system for 13 years (starting in 1997). The output: allows people to translate lafdziyyah/word (but not interpretation) when reading al-Quran without seeing the translation. ${ }^{9}$

\section{d. Granada method}

The Granada method, is a method of translating al-Quran developed by Solihin Bunyamin Ahmad, based on the desire to give the best for students to quickly understand the language of al-Quran. This method teaches how to translate al-Quran in 4 steps for 6 hours. By basing understanding of the Arabic language by making an inventory of the words in Arabic and their changes. The change returned to three letters, only a dozen did not.

Furthermore, dividing the changes to the Arabic word into prefixes, suffixes, and inserts. This term is adapted to Indonesian grammar that is already known by the public compared to Arabic grammar. For example a Muslim lafaz consisting of mi'm, sin, lam, and nun has an additional letter at the beginning, namely mim. Or the word karim, composed of kaf, ra ', yes, and mim. He got additional yes'. From these formulas, a one- page table or Nahwu Sharaf One. ${ }^{10}$

The steps are as follows;

1. First to master the components in Arabic. There are only three components in Arabic, namely: nouns, verbs and letters. What is meant by letters are all meaningful words that are neither a verb nor a noun, such as: in, about, and, for the sake, not and so on.

2. Second, mastering words that do not change (without root words), such as meaningful letters, pronouns, conjunctions and indicative words. To master meaningful letters requires patience in practice and often read them repeatedly or memorize them.

3. Third, to master the Granada formulas and their application is to look for word roots, active-passive patterns and disease letters.

4. Fourth, istiqamah training. This istiqamah exercise is assisted by several tools, such as a dictionary, the al-Qur'an translation of the Indonesian Min istry of Religion and Ibn Kathir's Tafsir and others that support it.

\section{e. Amsilati Method}

The Amsilati method was compiled by KH Taufiqul Hakim from the Darul Falah Islamic Boarding School, Bangsri, Jepara, Central Java. This method uses books compiled by KH. Taufiqul Hakim is to learn Arabic grammar with examples taken

\footnotetext{
${ }^{9}$ http://rikeu2000.wordpress.com,/tikror/ 1 April 2018

${ }^{10}$ SoilihinBunyaminAhmad, PanduanBelajardanMengajar8 JamBisaMenerjemahkanAlQur'anMetodeGranadaSistem4Langkah(TangerangSelatan: GranadaInvestaIslami, 2014), h:6-61
} 
directly from al-Quran and Hadith which consists of 10 volumes, namely 5 volumes of Amtsilati, 2 volumes of Tatimmah, 1 volume of Qa'idati, 1 volume of Khulashoh, and 1 volume of Sharfiyah.

Amsilati method learning techniques, according to Aminudur Yusuf Putra, are as follows:

1. First, within 1 week to 10 days students try to finish 1 volume. If there are students who have difficulty completing it within the time limit, keep studying until they finish the Amsilati volume that has not been mastered.

2. Second, 1 meeting takes 45 minutes, with the details of the first 10 minutes to repeat the qoidah formula from the previous lesson contained in the Qa'idati volume, then in the next 25 minutes to learn new material, and 10 minutes after that to memorize the qoidah formula that has been studied.

3. Third, in 1 day there are 3-4 meetings.

Fourth, the test in Amsilati learning is carried out, after the students have completed 1 volume of Amsilati, all of which are 5 volumes, and the test is carried out with a written test. Students are declared "passed" if the value of the test is more than nine, and if the score is less than nine, it is declared "did not pass".

\section{RESEARCH METHOD}

This is qualitative research, the research approach is a phenomenological perspective and a descriptive analysis approach, data sources are primary data and secondary data, data collection techniques through observation, interviews, and documentation. Research instruments, namely, researchers as key instruments, observation guides, interview guidelines and documentation references, data processing and analysis techniques, namely data reduction, data presentation, conclusion and verification, data validity testing, namely triangulation techniques, checking the correctness of information, discussing and consulting data, and extension of research time.

\section{RESULT AND DISCUSSION}

The implementation of the Safinda method in learning the translation of alQuran for students at IAIN Fattahul Muluk Papua is carried out through the planning of the Safinda method in learning the translation of al-Quran, implementing the Safinda method in learning the translation of al-Quran, evaluating the Safinda method in learning translation al-Quran.

a. Planning for the Implementation of the Safinda Method in Learning Al-Qur'an Translation at IAIN Fattahul Muluk Papua

The Safinda method planning in learning the translation of al-Quran is related to determining what will be done in applying the Safinda method in learning the translation of al-Quran. Planning for the application of the Safinda method in learning the translation of al-Quran is an activity that precedes the implementation of learning which functions to determine what and how to achieve the stated goals. Planning is an effort to determine the activities to be carried out in the future. This activity is 
intended to organize various resources so that the results achieved are by what is expected in learning.

Planning for the application of the Safinda method in learning the translation of al-Quran is an activity plan that is systematically structured, functions to direct all learning activities so that the objectives of implementing the Safinda method in learning the translation of al-Quran can be achieved.

In connection with the planned implementation of learning methods Safinda in the translation of al-Quran in IAIN Fattahul Muluk Papua, researchers way with the lecturer in charge of teaching methods in learning Safinda translation of alQuran follows:

"In planning the implementation of the Safinda method in learning the translation of al-Quran, an annual program, a semester program is prepared. Especially in planning the Safinda method in learning the translation of al-Quran, it contains first the learning objectives; second learning material; the three approaches and models; the four learning activities include preliminary/initial activities, core activities, closing; five assessments of learning, remedial and enrichment; the six media, tools/materials, and learning resources." 11 follows:

Relating case the above, the authors conducted interviews with faculty as

"In designing a planning application in teaching methods Safinda translation of al-Quran, not spontaneous, but before I rearrange the planning application Safinda method in teaching translation of al-Quran I overdue and prepare myself as well as possible physical preparation, mentally, as well as the subject matter to be taught." 12

The results of the interview above indicate that there is a planning for implementing the Safinda method in learning the translation of al-Quran at IAIN Fattahul Muluk Papua which can be understood that the lecturer in designing the lesson plan considers and prepares himself or mentally includes the inner attitude of the lecturer. Mental preparation in melaksana right teaching faculty are committed and love the profession of educators in helping students to find out the translation of alQuran.

The planning of implementing the Safinda method in learning the translation of al-Quran at IAIN Fattahul Muluk Papua which is carried out by lecturers takes into account and considers the abilities of students because of student abilities vary. This consideration is the right step because planning the implementation of the Safinda method in learning the translation of al-Quran at IAIN Fattahul Muluk Papua is a mapping of steps towards the goal. Within this framework, learning planning is absolutely done by the lecturer. Planning defenders jar 's or instructional design helps faculty directing and performance measures and activities that will be displayed in the

Maret, 2019

${ }^{11}$ A. Ubaidillah, Lecturer of Safinda Method IAIN Fattahul Muluk Papua. Interview, Papua, 8 Maret, 2019.

${ }^{12}$ A. Ubaidillah, Lecturer of Safinda Method IAIN Fattahul Muluk Papua. Interview, Papua, 8 
process of implementation of the method of learning Safinda translation of alQuran in IAIN Fattahul Muluk Papua.

Considerations and what the lecturers pay attention to in planning the implementation of the Safinda method in learning the translation of al-Quran at IAIN Fattahul Muluk Papua, the composition includes at least five things called the planning format for implementing the Safinda method in learning the translation of alQuran at IAIN Fattahul Muluk Papua based on interactive learning, namely; defenders purpose horse, learning materials, strategies or teaching methods, learning resources, and learning outcomes.

Researchers made observations on the implementation of the Safinda method in learning the translation of al-Quran at IAIN Fattahul Muluk Papua, it was proven that the lecturers who implemented the Safinda method in learning the translation of alQuran at IAIN Fattahul Muluk Papua prepared planning before carrying out the learning.

Based on the results of observations and interviews, it shows that lecturers who implement the Safinda method in learning the translation of al-Quran at IAIN Fattahul Muluk Papua, before carrying out the learning, prepare their lesson plans as a reference in learning so that the process of applying the Safinda method in learning the translation of al-Quran at IAIN Fattahul Muluk Papua focused and easy to evaluate success, and lecturers apply what has been designed before, and can detect student learning outcomes.

Planning for the implementation of the Safinda method in learning the translation of al-Quran at IAIN Fattahul Muluk Papua is preparation for learning activities chosen by lecturers to achieve predetermined teaching goals. In planning the implementation of the Safinda method in learning the translation of al-Quran at IAIN Fattahul Muluk Papua, it is arranged so that the learning process takes place interactively, inspires, is fun, efficient, and motivates students to participate actively in the process of applying the Safinda method in learning Al-Qur 'translation. an in IAIN Fattahul Muluk Papua.

D nature of planning application Safinda method in teaching translation of alQuran in IAIN Fattahul Muluk Papua lecturer lesson plan for mem simplify and improve the process of learning activities and improve learning outcomes, the better planning at interchanges, will be the easier implementation of learning activities, so that the higher the results that can be achieved.

The planning framework for implementing the Safinda method in learning the translation of al-Quran at IAIN Fattahul Muluk Papua involves a sequence of steps that are very important for lecturers in preparing the implementation of the plan for implementing the Safinda method in learning the translation of al-Quran at IAIN Fattahul Muluk Papua.

The researcher continued the interview with one of the lecturers who managed the implementation of the Safinda method in learning the translation of alQuran at IAIN Fattahul Muluk Papua, as follows:

"In the framework of planning the implementation of the Safinda method in learning the translation of al-Quran at IAIN Fattahul Muluk Papua, it limits the number of special activities that will be completed by the lecturer, namely there are six activities. Within this framework, there is a close relationship between the six activities, namely first diagnosing student 
needs; second selecting content and specifying suggestions; the third identifies learning techniques; The fourth plan activities or formulate unit -unit lesson Safinda; fifth provides program motivation; the sixth measurement, evaluation, and level determination. ${ }^{13}$

From the results of the interview above, the authors understand that the planning framework for implementing the Safinda method in learning the translation of al-Quran at IAIN Fattahul Muluk Papua diagnoses the needs of students, meaning that the lecturers pay special attention to the students in the class. Among other things related to the interests of individuals, their needs and abilities in reading al-Quran. Furthermore, we look for a way out how to fulfill this. Besides that, the lecturer also determines the learning materials that are selected and taught to students. These answers or efforts will be able to help the lecturer to move on to the next activity

From the results of the interview above, the writer understands that the planning framework for implementing the Safinda method in learning the translation of al-Quran at IAIN Fattahul Muluk Papua is selecting content and determining suggestions. The teaching objectives describe what is expected of students so that they can do something by the learning sequence so that the lecturers can know that the student has previously studied the Safinda method in the class. In this connection, the lecturers also consider the individual differences in the class during teaching.

From the results of the interview above, the author understands that the planning framework for implementing the Safinda method in learning the translation of al-Quran at IAIN Fattahul Muluk Papua identifies learning techniques. This activity is carried out because the lecturer already knows certain targets that can be used as a basis for making a decision. Lecturers can freely choose each learning technique, so it is a professional adjustment, and this kind of action can help students to achieve predetermined goals.

From the results of the above interviews, the authors understand that the planning framework for implementing the Safinda method in learning the translation of al-Quran at IAIN Fattahul Muluk Papua plans activities to formulate units and plan lessons. In this activity, the most important thing is to organize the decisions that have been taken, namely regarding individual students, goals, and learning techniques and recorded in official documents, so that they can be used to continue the next learning.

From the results of the interview above, the authors understand that the planning framework for implementing the Safinda method in learning the translation of al-Quran at IAIN Fattahul Muluk Papua provides motivation and program implementation. Planning for this activity prepares the lecturer specifically regarding the motivational techniques to be applied and several administrative procedures that need to be followed so that the teaching plan can be implemented properly. About these assignments and activities, there is a very important decision that must be made, namely determining the transition between one part of the lesson given that day to the lesson in the following days.

${ }^{13}$ A. Ubaidillah, Lecturer of Safinda Method IAIN Fattahul Muluk Papua. Interview, Papua, 8 Maret, 2019. 
From the results of the interview above, the writer understands that the planning framework for implementing the Safinda method in learning the translation of al-Quran at IAIN Fattahul Muluk Papua is the last activity, namely planning that is focused on measurement, evaluation, and level determination. This activity is a planning development for conducting tests and adjustments to individual student performances. It should be noted that there is a relationship between measurement, evaluation and leveling with the other six activities contained in the framework as outlined above. Thus there is a direct relationship between each of these activities.

The preparation of planning for the implementation of the Safinda method in learning the translation of al-Quran at IAIN Fattahul Muluk Papua applies pedagogical principles so that students gain effective learning experiences in developing attitudes, knowledge and skills by predetermined learning objectives. The planning design for implementing the Safinda method in learning the translation of al-Quran at IAIN Fattahul Muluk Papua is rich in innovations by the specifications of teaching materials and student learning environments (natural resources and local culture, community needs and developments in science and technology).

Research through interviews, observation and documentation of the lecturers at IAIN Fattahul Papua Muluk can be said to be very attentive to the learning plan so that the application of learning methods Safinda in the translation of al-Quran in IAIN Fattahul Papua Muluk run with the maximum.

\section{b. Implementation of the Safinda Method in Learning Al-Qur'an Translation at IAIN Fattahul Muluk Papua}

Implementation Safinda method in teaching translation of al-Quran in IAIN Fattahul Papua Muluk a Training Program Translation of al- Quran the translation of the method of al- Qur " an immediate well as the grammar of the Arabic language in a simple, easy and practical.

The implementation of the Safinda method in learning the translation of alQuran at IAIN Fattahul Muluk Papua is a practical and systematic method for reading al-Quran. The practical method means that this method can be successful according to the target (reading al-Quran) in a short period. While the systematic method means that this method is arranged systematically according to student development.

In connection with the implementation of the Safinda method in learning the translation of al-Quran at IAIN Fattahul Muluk Papua, the author conducted interviews with lecturers who taught the Safinda method in learning the translation of al-Quran at IAIN Fattahul Muluk Papua, as follows:

"The implementation of the Safinda method in learning the translation of alQuran at IAIN Fattahul Muluk Papua is very good because it emphasizes directly on reading exercises. This also includes making it easier for students and lecturers to learn because it has a guide starting from a simple level, step by step to the perfect level. Make it easy for every student who studies and teaches al-Quran. In practice, the Safinda method in learning the translation of al- 
Quran does not require a variety of tools, because it is emphasized in the reading."14

Based on the description of the interview above, it can be said that basically in implementing the Safinda method in learning the translation of al-Quran at IAIN Fattahul Muluk Papua, lecturers are required to master the Safinda method before teaching and how to convey the material must also be based on the tools used has been provided.

In principle, the application of the Safinda method in learning the translation of al-Quran at IAIN Fattahul Muluk Papua is the same as other subjects including classroom management activities, introductions, core activities, and closing activities.

The following is a more detailed explanation of classroom management, preliminary activities, core activities, and closing activities of the Safinda method in learning the translation of al-Quran at IAIN Fattahul Muluk Papua:

\section{Class management}

Frame application Safinda method in teaching translation of al-Quran in IAIN Fattahul Muluk Papua through classroom management, two main elements are important to note, that a classroom setting and management students. The author will explain these two elements through interviews and observations, as follows:

\section{a. Classroom arrangement}

The implementation of the Safinda method in learning the translation of alQuran at IAIN Fattahul Muluk Papua through class management, especially in the arrangement of classrooms is implemented in the learning process as stated by the lecturer who applies the Safinda method in learning the translation of al-Quran at IAIN Fattahul Muluk Papua:

"I do classroom management, including arranging the physical environment of the class in a clean and comfortable state. The physical environment of the classroom is kept clean and the classroom must be swept and cleaned every day. $" 15$

Researchers made observations in the classroom that based on the results of observations of all classes used in the implementation of the Safinda method in learning the translation of al-Quran at IAIN Fattahul Muluk Papua, the lecturers implemented classroom management through classroom arrangement, including partial image media that had been neatly prepared in class. The arrangement of classrooms looks neat, due to supporting factors, the campus already has trash bins, brooms, garbage collectors, and dust cleaners and boarders of the dormitory are also responsible for cleanliness in the classroom.

Space classroom clean and tidy necessarily healthy for faculty and students themselves. Lecturers and students feel more comfortable because the classrooms are free of scattered trash or dust that makes lecturers and students feel comfortable in the classroom.

\footnotetext{
Maret, 2019.

${ }^{14}$ A. Ubaidillah, Lecturer of Safinda Method IAIN Fattahul Muluk Papua. Interview, Papua, 15

${ }^{15}$ A. Ubaidillah, Lecturer of Safinda Method IAIN Fattahul Muluk Papua. Interview, Papua, 15 Maret, 2019.
} 
In addition to the arrangement of classrooms, seating arrangements must be flexible; it will make it easier for lecturers to move in all directions, and make students feel comfortable learning. Most of the classrooms are filled with desks and benches or chairs that are used by students as seats. Therefore, special arrangements are needed so that the seats can be neatly arranged and allow students to study comfortably.

The results of interviews with lecturers who apply the Safinda method in learning the translation of al-Quran at IAIN Fattahul Muluk Papua are as follows:

"I make student seating arrangements flexible. Namely, the composition changes according to the needs, for example by arranging student seats so that all students can face one direction. I usually apply several kinds of seating formations but the one I do most often is the horseshoe formation so that students can easily be monitored."16

Based on the interview above, the lecturer does the application Safinda method in teaching translation of al-Quran in IAIN Fattahul Muluk Papua implement classroom management about the seating arrangements were mixed and flexible, or media used to be a lecturer move in all directions for supervising all students. Seating arrangements for students must allow lecturers and students to feel comfortable in the learning process. Seating arrangements are often changed so as not to bore students.

b. Student management

Student management is closely related to the skills of lecturers in creating and maintaining optimal learning conditions for students to prevent students from being interrupted in the process of implementing the Safinda method in learning the translation of al-Quran at IAIN Fattahul Muluk Papua.

Student management is a lecturer skill to create and maintain an optimal learning atmosphere and be able to restore it when there is a disruption in the teaching and learning process. For example, to stop the aberrant behavior of students and disrupt the concentration of another friend, or reward (reward) for students who do the work on time and so forth. In its role as a learning manager or learning manager, lecturers at IAIN Fattahul Muluk Papua can manage students.

The results of an interview with a lecturer who applied the Safinda method in learning the translation of al-Quran at IAIN Fattahul Muluk Papua, are as follows:

"In carrying out student management, I display good student behavior and reduce or suppress bad student behavior. If students show good behavior such as obeying rules, listening to lecturers' explanations in front of the class, making or doing assignments given by the lecturer, making the learning process easier. Student behavior that is not good even if it is only done by one or a group of students will greatly disrupt the smoothness of the learning process."17

Based on the results of the interview above, the lecturer always overcomes the unfavorable student behavior and displays the student's good behavior. Praise is given to students who behave well while reprimands are given to students who behave badly. Maret, 2019

${ }^{16}$ A. Ubaidillah, Lecturer of Safinda Method IAIN Fattahul Muluk Papua. Interview, Papua, 15 Maret, 2019.

${ }^{17}$ A. Ubaidillah, Lecturer of Safinda Method IAIN Fattahul Muluk Papua. Interview, Papua, 15 
Lecturers reinforce annoying students, namely by approaching the student when he is doing an unnatural behavior, then reprimanding him.

But the reprimand given by the lecturer to students who behave badly is not given roughly, hurtfully, contains insults, babbles, and even excessive ridicule. Creating good relationships between individuals and a healthy socioemotional state. Students will be together in a classroom for several hours.

Therefore, the relationship between lecturers and students is well developed based on healthy socio-emotional relationships. Thus, it is easier for lecturers to build interactions among students which are very important in the learning process. Good relationships between lecturers and students or fellow students can be built if an effective communication climate is created between lecturers and students or close friendship between fellow students to maximize the implementation of the Safinda method in learning the translation of al-Quran at IAIN Fattahul Muluk Papua.

\section{Preliminary activities}

Preliminary activities in the process of applying the Safinda method in learning the translation of al-Quran at IAIN Fattahul Muluk Papua means opening lessons which are lecturers' efforts to create an atmosphere that is mentally prepared and generate student attention to focus on what is being learned. The implementation of the Safinda method in learning the translation of al-Quran at IAIN Fattahul Muluk Papua is related to preliminary activities that can be dictated through interviews and observations.

The author of interviews with lecturers who apply the Safinda method in learning the translation of al-Quran at IAIN Fattahul Muluk Papua, is as follows:

"In the preliminary activities, we were guided by the planning that had been prepared. The initial activities included greeting, attending, praying, and giving the motivation to arouse curiosity, pay attention to class management and student management. For example, moving the seat of a student who is always waiting for a friend." $" 18$

Based on the interview statement above, it shows that the initial activities of the lesson were applied by lecturers who applied the Safinda method in learning the translation of al-Quran at IAIN Fattahul Muluk Papua starting with the greeting, praying, and giving motivation to students. The initial activity in implementing the Safinda method in learning the translation of al-Quran at IAIN Fattahul Muluk Papua is an activity as a first step to foster student motivation to be eager to receive the subject matter.

The researcher continued the interview with the students who joined in learning the terms of al-Quran through the Safinda method in learning the translation of alQuran at IAIN Fattahul Muluk Papua as follows:

"Usually, lessons always begin with reading a prayer together and given motivation by the lecturer. ${ }^{19}$ It was common for lecturers to attend

${ }^{18}$ A. Ubaidillah, Lecturer of Safinda Method IAIN Fattahul Muluk Papua. Interview, Papua, 15 Maret, 2019.

${ }^{19}$ M. Fikram S, Student from Safinda Method IAIN Fattahul Muluk Papua. Interview, Papua, 22 Maret, 2019. 
classes at the beginning of the lesson, arrange seats, ask about health conditions, provide motivation and study readiness." 20

Researchers made observations and the results of observations showed that the lecturer paid attention to the class by giving a comprehensive view of all students until everything was calm, then said greetings and recited prayers. During the implementation of the lessons of al-Qur'an additional material has given that the implementation of the learning method Safinda in the translation of al-Quran in IAIN Fattahul Papua Muluk not boring fast and effective as a prayer-daily prayer, reading the prayer, short letters or rote other memorization.

Further observations in the application of the Safinda method in learning the translation of al-Quran at IAIN Fattahul Muluk Papua in the preliminary activities carried out are that first the learning process begins with greetings from the lecturer, followed by reading the opening prayer.

Observation then the lecturer absent to know the presence of students and classical learning begins with the lecturer reviewing the additional material yesterday, and adding additional material. Then proceed with explaining the subject matter by reading the examples over and over again, loud, clear, and correct because the students prefer to listen, imitate rather than listen to writing. Students imitate and read verse pieces that have been prepared to practice togetherness.

Based on the results of interviews with several informants and the results of observations, it can be confirmed that the lecturer carries out learning guided by the planning framework and in the initial activities, the lecturer reads prayers with students, takes attendance, and motivates students, and pays attention to student learning readiness both physically and psychologically.

The implementation of the Safinda method in learning the translation of alQuran at IAIN Fattahul Muluk Papua through fun preliminary activities in the learning process. This means that the activity of opening lessons is a lecturer effort to create an atmosphere that is mentally prepared and raises student attention so that it is focused on what is being studied.

The implementation of the Safinda method in learning the translation of alQuran at IAIN Fattahul Muluk Papua through fun preliminary activities can be taught through interviews and observations.

The author of the interview with the organizer of the implementation of the Safinda method in learning the translation of al-Quran at IAIN Fattahul Muluk Papua is as follows:

"In the preliminary activity put forward specifically and briefly so that it allows students to get a clear picture of the things to be studied and the way to be taken in studying the learning material." 21

The researcher continued the interview with students who took the Safinda method application program in learning the translation of al-Quran at IAIN Fattahul Muluk Papua, as follows:

\footnotetext{
${ }^{20}$ Muhammad Tamsil, Student from Safinda Method IAIN Fattahul Muluk Papua. Interview, Papua, 22 Maret, 2019.

${ }^{21}$ A. Ubaidillah, Lecturer of Safinda Methode of IAIN Fattahul Muluk Papua. Interview, Papua, 22 Maret, 2019.
} 
"Usually, when the lesson starts, it always begins with reading a prayer together and being motivated by the lecturer and conveying the methods that will be applied in learning." 22

"At the beginning of the lesson, the lecturer always asked us about the past week's lesson material, and told us the lesson objectives to be achieved." 23

"It is common for lecturers to attend classes at the beginning of the lesson, arrange seats, ask about health conditions, provide motivation and study readiness." 24

According to one of the lecturers who applied the Safinda method in learning the translation of al-Quran at IAIN Fattahul Muluk Papua in an interview, it was stated as follows:

"In the introduction, learning is carried out in an interactive, inspirational, fun, challenging manner, motivates students to actively participate, and provides sufficient space for students to be creative, so that learning can run smoothly. Besides, we compare it with new knowledge with knowledge already known to students, and we as lecturers explain the concept first and then explain it in detail." 25

To strengthen the previous informant's explanation, the researcher continued the interview with the lecturer.

"In the introduction, learning is carried out, namely stating the objectives and boundaries of the task, suggesting steps to be taken, reminding the main problems to be discussed, and asking relevant questions and the material to be studied, and making lesson links by connecting the material that will be discussed. Students have mastered the material to be delivered." 26

Based on the interview expressions from several informants, it shows that the initial activities of implementing the Safinda method in learning the translation of alQuran at IAIN Fattahul Muluk Papua started with praying to give motivation to students. The initial activity in learning is an activity as a first step to foster student motivation to be eager to receive subject matter.

The essence of opening the activity of implementing the Safinda method in learning the translation of al-Quran at IAIN Fattahul Muluk Papua is delivering hook/apperception material, motivating students to start learning, and conveying the competencies that students must achieve.

In the implementation of the Safinda method in learning the translation of alQuran at IAIN Fattahul Muluk Papua, it is not only about telling learning materials to Maret, 2019.

${ }^{22}$ Hendriyanto, Student from Safinda Method IAIN Fattahul Muluk Papua. Interview, Papua, 22

${ }^{23}$ Muhammad Arfah, Student from Safinda Method IAIN Fattahul Muluk Papua. Interview, Papua, 22 Maret, 2019.

${ }^{24}$ Fadel Anshori Mulihat, Student from Safinda Method IAIN Fattahul Muluk Papua. Interview, Papua, 22 Maret, 2019. Maret, 2019.

${ }^{25}$ A. Ubaidillah, Lecturer of Safinda Method IAIN Fattahul Muluk Papua. Interview, Papua, 29 Maret, 2019.

${ }^{26}$ A. Ubaidillah, Lecturer of Safinda Method IAIN Fattahul Muluk Papua. Interview, Papua, 29 
students, but also about the mental involvement and actions of the students themselves. Not only providing explanations and demonstrations, but it also does not produce optimal learning outcomes. Optimal learning outcomes are obtained from a learning process involving students in activities and developing their creativity. In the learning process of the application of the Safinda method in learning the translation of al-Quran at IAIN Fattahul Muluk Papua students are not passive but participate. Lecturers as motivators can motivate students to always be enthusiastic in participating in learning until the end of the implementation of the Safinda method in learning the translation of al-Quran at IAIN Fattahul Muluk Papua.

Noting the description above, the lecturer who applies the Safinda method in learning the translation of al-Quran at IAIN Fattahul Muluk Papua acts as an inspiration, the lecturer can explore and develop the inspiration that students have so that students optimally demonstrate their ability to translate al- Quran. In simple terms, all of the above concepts can be applied in the opening activity of the application of the Safinda method in learning the translation of al-Quran at IAIN Fattahul Muluk Papua.

Lecturers who apply the Safinda method of learning in knowing the actions they take when opening lessons. The activity of opening lessons skills is a very important component in the learning process, so that the lecturers give serious attention to this problem. This is because the process of opening lessons skills is the estuary of the success of the core activities of implementing the Safinda method in learning the translation of al-Quran at IAIN Fattahul Muluk Papua. Errors in opening lesson skills have a direct effect on student learning outcomes.

\section{Core Activities}

Researchers conducted interviews with lecturers who implemented the Safinda method in learning the translation of al-Quran at IAIN Fattahul Muluk Papua, as follows:

"The reason for choosing the Safinda method in learning the translation of alQuran at IAIN Fattahul Muluk Papua is applied to the translation lessons of alQuran in the campus dormitories because in my opinion using this method has many positive aspects seen from the results of learning to translate al-Quran ' students taught. Safinda method in teaching translation of al-Quran which adopts a translation of al-Quran in harfiyah very easier for students to understand the translation of al-Quran." 27

Success in learning is very much dominated by learning methods that are by the material presented. The Safinda method in learning the translation of al-Quran at IAIN Fattahul Muluk Papua which adopts the literal translation of al-Quran makes it very easy for students to understand the translation of al-Quran . Students can easily find out the meaning of al- Qur'an verbatim, so that students can understand much about Arabic vocabulary. Besides, students also get additional grammar in the form of nahwu and sharaf knowledge which is given gradually from juz to juz is not given all at once.

${ }^{27}$ A. Ubaidillah, Lecturer of Safinda Method IAIN Fattahul Muluk Papua. Interview, Papua, 5April, 2019. 
Subsequent interviews with lecturers who applied the Safinda method in learning the translation of al-Quran at IAIN Fattahul Muluk Papua, were as follows:

"The application of the Safinda method in learning the translation of alQuran at IAIN Fattahul Muluk Papua in addition to providing grammar material also presents Arabic literature teaching which is a high-level science in language understanding, namely balaghah, mantiq, ma'ani and others. However, the Arabic literary material is given in the last chapters because it is very difficult for the lesson to be taught to novice students." 28

Subsequent interviews with students, who participated in the application of the Safinda method in learning the translation of al-Quran at IAIN Fattahul Muluk Papua, were as follows:

"I am very happy to follow Safinda's method in learning the translation of alQuran because it does not focus on memorizing too much by using this method because if we memorize too much, of course we as students will feel bored and have no interest in learning anymore." 29

The Safinda method in learning the translation of al-Quran at IAIN Fattahul Muluk Papua is specially designed for people who want to understand al-Quran but have never stepped into the world of Islamic boarding schools. In addition to the factors above, the reasons for choosing the Safinda method in learning the translation of al-Quran at IAIN Fattahul Muluk Papua have been mentioned because this method provides knowledge and practice to teach the science of nahu, neuroscience, balaghah science without memorizing the theories.

The implementation of learning using the Safinda method in learning the translation of al-Quran at IAIN Fattahul Muluk Papua has been planned in the form of a preparation program. Besides that, the lecturer carries out the formulation of the objectives to be achieved, utilizes the tools that have been provided before teaching, uses a place that has been arranged and uses the estimated time before carrying out learning.

The teaching method applied in the application of the Safinda method in learning the translation of al-Quran at IAIN Fattahul Muluk Papua is as follows:

The implementation of the Safinda method in learning the translation of alQuran at IAIN Fattahul Muluk Papua, the learning time ranges from 80-90 minutes and is divided into three parts, namely:

First, about 15-20 minutes for the lecturer to read greetings as an opening, read al-Fatihah and the verse which is the material, students read al-Fatihah and the verse read by the lecturer, attendance, explain the subject of the lesson (which will be translated) and students are asked to read together -the same one until three times.

Second, about 40-50 minutes to teach individually/listen to students one by one patiently, thoroughly and firmly, the lecturer admonishes the wrong reading of students with a knock signal, if it is not possible, then it is shown how to read

${ }^{28}$ A. Ubaidillah, Lecturer of Safinda Method IAIN Fattahul Muluk Papua. Interview, Papua, 5 April, 2019.

${ }^{29}$ Khaedar Yunus, Student from Safinda Method IAIN Fattahul Muluk Papua. Interview, Papua, 5 April, 2019. 
correctly, because in practice the lecturer also pays attention tajwid do not let students read wrong.

Third, about 15-20 minutes, the lecturer gives additional prayer lessons, collects writings while the lecturer corrects if possible and continues with a closing prayer.

The learning process both begins and ends at Asr at 15.30 and ends at 17.00. The methods used are classical and individual, meaning that learning begins with the lecturer 's explanation of the material, which is then followed by an individual method, in which students read the lafadz one by one in front of the lecturer. Then the lecturer listens carefully and patiently if there is an error. If there is an error, the lecturer taps as a sign there is an error, if the student is no longer able to then be shown the correct way to read.

The results of the observations show that the lecturer as the guide also reads word for word from the verses of al-Quran which are followed by the students. This aims to make students know and listen to the words to be studied. After this is done, the lecturer and students read again word for word but this is followed by describing nahwu and sharaf. Because nahwu knowledge as the mother of knowledge and sharaf as the father of knowledge. Thus it will produce a good Arabic composition.

The results of the next observation were the students' next step to read the words and then the lecturer interpreted them; this was so that the students could understand in detail the meaning of the words.

The results of the next observation that the students read simultaneously from all the verses that have been interpreted word for word, this is done so that students can interpret the meaning that has been learned into a good sentence in interpreting the verses of al-Quran.

The results of observations of the implementation of the Safinda method in learning the translation of al-Quran at IAIN Fattahul Muluk Papua apply two learning systems at once, namely the classical system and the individual system. The classical system is applied when new learning begins, that is, after students read the opening prayer then the lecturer explains the main material together (classical), and continues with individual learning.

The results of the observation that all the steps were taken, then the students were randomly assigned to read the material they had studied, this also tested the students' ability to understand how well the students understood the material. Besides, lecturers also provide opportunities for students to ask questions about material that students have not understood.

The result of observation is that the last step in the learning process is that the lecturer explains the meaning contained in the verses that have been studied clearly.

Through the application of the Safinda method in learning the translation of alQuran at IAIN Fattahul Muluk Papua which has been mentioned above, it can be said that this method is very easy for the way of learning because it is not too complicated in the learning application.

The results of subsequent observations show that the props that have been provided by the organizers of the Safinda method in learning the translation of alQuran at IAIN Fattahul Muluk Papua are easy to use, namely on the sheets there are two colors in the print. Red color for lafadz that have never been studied and memorized by students. And if in the next lafadz there is a lafadz that is the same as 
the verse that has been conveyed, then the lafadz is printed in black. The more lafadz that has been studied, the less lafadz will be printed in red. Many red lafadz prints are found in the letter al-Baqoroh so that many of the letters after that are printed in black. In the last juz, there were almost no red lafadz prints.

In the core activities of implementing the Safinda method in learning the translation of al-Quran at IAIN Fattahul Muluk Papua, the lecturers carry out several activities as follows:

\section{a. Reading Activities}

Reading activity is seeing and understanding the content of what is written (by speaking or only by heart). This reading activity assumes that the process of applying the Safinda method in learning the translation of al-Quran at IAIN Fattahul Muluk Papua is carried out directly and intensively in reading. Meanwhile, writing skills can be developed later. Therefore, students are accustomed to reading practice both directly and indirectly

The results of interviews with lecturers are as follows:

"In applying this method, the lecturer gives high priority to the skills to read the translation of al-Quran. The learning base focuses on reading techniques to understand, where students repeating words, through text associations that have been provided by the lecturer."30

To strengthen the informant's statement, the researchers conducted classroom observations during the process of applying the Safinda method in learning the translation of al-Quran at IAIN Fattahul Muluk Papua. In this activity, the attention and participation of students in learning activities look enthusiastic, students are very enthusiastic to actively participate in the reading that is being studied, because it is enough to listen and follow, whether it is read by lecturers, or read by students.

In the normal reading student and understand the contents of what is written in the text of al-Quran and translate (by express or only in the liver). Activity involves two activities that see and understand. Reading activity means seeing the text of alQuran and understanding the meaning, meaning, or translation of al-Quran. The object that is read in this case is the text of al-Quran and its translation which is understood by the reading student, therefore, students who can read the text without understanding the meaning or meaning are not included in the reading. A person can read a few words, but if he doesn't understand the meaning, that activity is not called reading.

Reading activity is saying something that has been memorized, so it does not involve any written text seen by the sense of sight by the written topic. This is because reading what is meant is attached to the word al-Qur'an which is a learning material on the application of the Safinda method in learning the translation of al-Quran at IAIN Fattahul Muluk Papua. Read in this study did not involve aspects interpretations $n$ meaning is being read or translation of the Qur'an that is being read. The purpose of learning to read the text of al-Quran is only so that students can memorize words and words so that as Muslims they have the basic ability to read and translate al-Quran.

${ }^{30}$ A. Ubaidillah, Lecturer of Safinda Method IAIN Fattahul Muluk Papua. Interview, Papua, 12 April, 2019. 
The activity of reading the text of al-Quran and its translation is an activity of reciting what is written in the text of al-Quran and its translation. Reading alQuran alone in Islam is already a valuable form of worship with Allah. Therefore, Muslims are encouraged to compete to learn to read al-Quran and its translation properly.

If you want the best results and a high degree of application of the Safinda method in learning the translation of al-Quran at IAIN Fattahul Muluk Papua, then the lecturer will carry out reading, memorizing, pondering, and practicing al-Quran. The four activities are related to one another. However, according to the author, the first activity that must be done is reading. Without the ability to read al-Quran and its translation, students are very unlikely to be able to memorize, ponder, let alone practice them.

The results of observations in the reading stage of the lecturer began by reading the text that had been prepared; students classically imitated each lecturer after reading. After that the students reread in turn, until all the students had finished reading. Then the stage of interpreting word for word, the lecturer reads by interpreting word for word, students imitate it classically, until it's finished, then students are allowed to repeat it in turn. If a student's ability is known, then the smartest one is given the opportunity first, and the one with the lowest absorption is given the last chance.

Reading activities on the application of the Safinda method in learning the translation of al-Quran at IAIN Fattahul Muluk Papua involve spelling or reciting activities, without involving understanding the meaning. For example, spelling or reciting the text of al-Quran and its translation which is a written language without knowing its meaning can be called reading in a simple sense. However, the activity of reading al-Quran accompanied by understanding the meaning and meaning is of course better and more important.

In carrying out their duties in managing to learn, lecturers face several students who are different from one another in terms of their physical, mental intellectual, nature and socioeconomic background. Lecturers may not be able to serve all students by paying attention to individual differences from one another in limited study hours.

Based on the results of interviews and observations that the application of the Safinda method in learning the translation of al-Quran at IAIN Fattahul Muluk Papua is carried out through a direct method, namely the lecturers pay great attention to the context of presenting material orally, especially at the first meeting. In the next exercise, the lecturer displays the text and then reads it orally, before ordering students to read it. It is classified through classical, group and individual processes.

The activity of implementing the Safinda method in learning the translation of al-Quran at IAIN Fattahul Muluk Papua is carried out through the direct method giving students the freedom to display questions related to the material they have read.

This reading method assumes that mastery of all the skills of translating alQuran is impossible, and to be more realistic with the aim of learning to translate alQuran, reading skills are prioritized, of course without neglecting the portion of learning to write, listen, follow, and translate text.

The results of the interview with the lecturer are stated as follows: 
"The presentation step in the reading method is the first step, students are trained to pronounce it through intensive reading, and they are also trained to get it used to say it. Reading habits are intended only to help them read the text fluently. The second step, reading the text taken from several media that has been prepared either from the image or from the LCD. Usually it is started by the lecturer and then by the students by reading the text that is taught properly and then the students are asked to listen to and imitate the reading of the lecturer, either individually or collectively." 31

After the interview, the researcher continued the observation during the implementation of the Safinda method in learning the translation of alQuran at IAIN Fattahul Muluk Papua by using the reading method in the results of the observation, it was seen that the lecturer pointed to several words that were considered new in the text, then reading the translation sometimes also allowed students to read it either individually or collectively and read it several times, sometimes voices are heard and also voices cannot be heard. Each student reads it the lecturer asks to be ordered to read the text aloud while paying attention to the meaning.

\section{b. Aural-Oral Activity}

From this context, the Aural-Oral activities when implementing the Safinda method in learning the translation of al-Quran at IAIN Fattahul Muluk Papua departs from the basic assumption that translating al-Quran starts from listening to the translation of al-Quran and then saying it, of course before learning to read and write.

The following are the steps in the process of implementing the Safinda method in learning the translation of al-Quran at IAIN Fattahul Muluk Papua through this method according to the lecturers interviewed as follows:

"The first step is listening, in this step the students listen to the LCD, sometimes they are heard directly from the lecturer repeatedly, so that they can receive lessons on translating al-Quran. Second Repetitive Steps, this step is classified into two parts, namely (1) collective repetitive, in which students collectively repeat the learning material after the LCD or lecturers are repeated aloud, then in groups. If one of the groups is still stagnating, then the group will repeat this activity. (2) Individual repetitions were performed individually by students after collective repetition activities aloud. If one of them is still choking, then we as lecturers will repeat this activity to the group where there are still students who are chafing. The three steps of reading aloud, this step was realized by students by reading aloud what they had memorized and got from the process of speaking out, in addition to focusing their concentration on the activities of the sound of sentences and tenses." 32

Oral activities in the process of implementing the Safinda method of learning the translation of al-Quran at IAIN Fattahul Muluk Papua are supported by adequate professionalism of lecturers in enriching and innovating the process of applying the

${ }^{31}$ A. Ubaidillah, Lecturer of Safinda Method IAIN Fattahul Muluk Papua. Interview, Papua, 12April, 2019.

${ }^{32}$ A. Ubaidillah, Lecturer of Safinda Method IAIN Fattahul Muluk Papua. Interview, Papua, 12April, 2019. 
Safinda method in learning the translation of al-Quran at IAIN Fattahul Muluk Papua, then the strength aspect of this method will be realized sharply.

\section{c. Memorizing Activities}

In the core activity of applying the Safinda method in learning the translation of al-Quran at IAIN Fattahul Muluk Papua, the lecturer is memorizing activities that focus on studying language texts that refer to the vocabulary that has been prepared by the lecturer based on words from the Qur'an to be memorized.

In the explanation of the interview with the lecturer it is said, as follows:

"In this core activity, it is emphasized to memorize, namely the text of alQuran and its translation to be memorized depending on the reading that has been presented, and the subject matter consists of memorizing the translation of words without context, but translated according to short texts according to what has been prepared in learning media to memorize directly." 33

Interviews with students stated that:

"In the activity of memorizing pieces of the text of al-Quran and its translation for the first time, students as memorizers by reading and memorizing pieces of text or material that will be played in front of the lecturer at least three times." 34

The following interviews with students are as follows:

"Usually, after reading it by looking at a piece of text that has been prepared and feeling a shadow, then read it by rote (without seeing the piece of text it is usually repeated at least three times in one or three texts and the maximum is not limited. If it has been read and memorized three times it is still not their shadow or still not memorized, it needs to be increased to be memorized correctly and no new material is allowed." 35

Next interview:

"Usually in this memorization activity, after memorizing the pieces of the text of al-Quran and its translation fluently, then adding the next text so that one verse is perfect. These new materials are always memorized just like memorizing the first material, then they are linked by repeating the material that has passed, at least three times in this verse and the maximum is not limited to memorizing completely. But if the memorization material for one verse is not completely fluent, then usually it does not move to the next verse material." 36

\footnotetext{
${ }^{33}$ A. Ubaidillah, Lecturer of Safinda Method IAIN Fattahul Muluk Papua. Interview, Papua, 19April, 2019.

${ }^{34}$ Khaedar Yunus, Student from Safinda Method IAIN Fattahul Muluk Papua. Interview, Papua, 19 April, 2019. April, 2019.

${ }^{35}$ Irham Bayu, Student from Safinda Method IAIN Fattahul Muluk Papua. Interview, Papua, 19

${ }^{36}$ Amrul Muttaqin, Student from Safinda Method IAIN Fattahul Muluk Papua. Interview, Papua, 19 April, 2019.
} 
The researcher made observations when the core activity was taking place, and if you pay attention, it can be said that the emphasis on memorizing that is applied in the application of the Safinda method in learning the translation of al-Quran at IAIN Fattahul Muluk Papua is very concerned about memorizing. In its implementation, this method uses language that is easy to understand, so that students can easily understand the translation of al-Quran. This method pays close attention to the target language in the translation process of al-Quran, and not in the realm of studying the translation of al-Quran.

The results of further observations were the steps of the learning process through memorizing emphasis when applying the Safinda method in learning the translation of al-Quran at IAIN Fattahul Muluk Papua, it can be said that the lecturer started the presentation of the subject matter by displaying the text and reading some sample texts. After that the lecturer led the students to memorize the list of texts of al-Quran and their translations, and asked the students to demonstrate the memorization of the translation vocabulary that was taught previously.

Based on the results of the interviews and observations above, it can be ascertained that the lecturer applies the emphasis of translation memorization when applying the Safinda method in learning the translation of al-Quran at IAIN Fattahul Muluk Papua because in practice the lecturer asks students to open the reading text, and then guides them to read by translating it. The word for word to memorize. Then the lecturer asked the students to read the text in their heart and then try to translate it by word, and then correct the results of their wrong translation, and emphasize rote memorization in its implementation.

After the students memorized the material for this one verse, their rote was mastered with completely fluent rote, then it was continued by adding new verse material by reading the text of al-Quran and translating it first and repeating it as in the first material. After there is a shadow, then proceed with reading without looking until you memorize it correctly as is memorizing the first verse.

After getting the two verses memorized properly and smoothly, and there are no more mistakes, then the memorization is repeated starting from the first verse coupled with the second verse at least three times and the maximum is not limited. Likewise, stepping on the following verses until the time limit provided is up and on the material that has been targeted.

This rote learning activity was demonstrated, namely practicing the use of words by imitating a lecturer or native informant to facilitate memorization. Learning the translation of al-Quran at IAIN Fattahul Muluk Papua is carried out in stages, starting from listening skills then memorizing.

So in this activity, after memorizing several pieces of the Qur'anic text and their translation, the lecturer emphasized that it is murajaah because humans cannot be separated from the nature of forgetting. Because forgetting is an inherent identity in humans, it is with this consideration that memorization of translating the Al-Quran that has been achieved with difficulty is not lost. Regular rote repeating is the best way to overcome it.

In the observation results, it was found that there were two kinds of repetition in memorization carried out by students on the application of the Safinda method in learning the translation of al-Quran at IAIN Fattahul Muluk Papua, namely: 
First, repeating myself, this is done by reading the text of al-Quran and translating it silently without being heard by others. This method is one of the habits of scholars in the past to remind and strengthen their memorization. With this method, a person will be helped to remember the rote that he has previously accomplished.

Second, repeat by saying. This method helps students to maintain their memorization. With this method, he has indirectly trained his mouth and hearing in reciting and memorizing his reading. He will also increase his enthusiasm and continue to try to justify when there is a mispronunciation.

Broadly speaking adding to memorization is easier than keeping it because people who memorize are motivated to be able, while keeping or repeating memorization always coincides with laziness. The solution, the students made a special schedule every day to repeat their memorization. This requires patience and diligence.

In the application of the Safinda method in learning the translation of alQuran at IAIN Fattahul Muluk Papua, through the emphasis on repeating memorization regularly and repeatedly as a process of moving the al-Qur'an taxa and its translation which has been memorized from the left brain to the right brain in between the characteristic of the left brain is to memorize quickly, but it is also fast forgetting that the characteristic of the right brain is the memory which requires a long time to enter memory into it, but it is also able to maintain memories that have been memorized for quite a long time.

In the application of the Safinda method in learning the translation of alQuran at IAIN Fattahul Muluk Papua through the emphasis on memorization, which starts from listening to the text of al-Quran and the translation is then imitated to create a habit of translating al-Quran through practice and repetitive, students are trained to memorize directly, and there is no need to introduce the struct ure and analysis of the translation, just memorize it in this period.

According to this method, the most ideal is the presentation of native speakers so that the exercises automatically mimic the lecturers or those that have been prepared by the lecturers. In the application of this method, it is supported by lecturers who are good at utterance and intonation in pronouncing the text of al-Quran and the translation that is taught so that it makes it easier for students to follow them in memorizing activities.

\section{Closing Activities}

The activity of closing the application of the Safinda method in learning the translation of al-Quran at IAIN Fattahul Muluk Papua is not just saying closing greetings and hamdalah or prayers at the end of each learning activity, because these activities should be done every time an activity ends. However, what is meant by closing the Safinda method lesson in learning the translation of al-Quran at IAIN Fattahul Muluk Papua is a lecturer activity to end the lesson by restating the main points of the lesson so that students get a complete picture of the subject matter and learning outcomes that have been studied.

There are several attempts made by the lecturer to close the Safinda method lesson in learning the translation of al-Quran at IAIN Fattahul Muluk Papua, including: 
"In closing the Safinda method activities in learning the translation of alQuran at IAIN Fattahul Muluk Papua, namely summarizing or summarizing the main points of the lesson, providing psychological or social encouragement to students, providing instructions for the next lesson/topic, and conducting an evaluation of new subject matter done." 37

Closing the Safinda method lesson in learning the translation of alQuran at IAIN Fattahul Muluk Papua is a lecturer effort to provide a comprehensive picture of what has been learned, an effort to determine the success of students in absorbing lessons, and determining the starting point for the next lesson.

The activity closed the Safinda method lesson in learning the translation of alQuran at IAIN Fattahul Muluk Papua as an exit from the activity of implementing the Safinda method in learning the translation of al-Quran. The exit door can also give various impressions and messages to students.

\section{c. Evaluation of the Safinda Method in Learning Al-Qur'an Translation}

Evaluation in the application of the method of learning Safinda translation of al-Quran in IAIN Fattahul Muluk Papua done comprehensively. The ability of lecturers in learning assessment is one of the criteria for lecturer professionalism. Evaluation of the application of the Safinda method in learning the translation of al-Quran at IAIN Fattahul Muluk Papua to find out students' understanding of the subject matter, train courage and invite students to recall the material that has been given. The purpose of an evaluation is not only for students, but aims to evaluate lecturers who have implemented learning to achieve educational goals.

Evaluation of the application of the method of learning Safinda translation of al-Quran in IAIN Fattahul Papua Muluk comprehensively, researcher interviews with professors that manage the application of the method of learning Safinda translation of al-Quran in IAIN Fattahul Muluk Papua as follows:

"I evaluate the whole learning process is no doubt the initial evaluation enforcing the teaching, the final evaluation and follow-up." 38

"I rate and clicking evaluation of learning outcomes either associated with the cognitive, affective want any psychomotor." 39

"I do is evaluate each end of the educational process and there is also the evaluation of each semester. The purpose of learning evaluation is to measure students' ability to absorb lessons.

Furthermore, the researchers conducted interviews with students who actively participated in the implementation of the Safinda method in learning the translation of al-Quran at IAIN Fattahul Muluk Papua, as follows:

${ }^{37}$ A. Ubaidillah, Lecturer of Safinda Method IAIN Fattahul Muluk Papua. Interview, Papua, 26April, 2019.

${ }^{38}$ A. Ubaidillah, Lecturer of Safinda Method IAIN Fattahul Muluk Papua. Interview, Papua, 26April, 2019. 3Mei, 2019

${ }^{39}$ A. Ubaidillah, Lecturer of Safinda Method IAIN Fattahul Muluk Papua. Interview, Papua, 3Mei, 2019.

${ }^{40}$ A. Ubaidillah, Lecturer of Safinda Method IAIN Fattahul Muluk Papua. Interview, Papua, 
"In my opinion, the lecturer always gives evaluations, for example, firstly the initial evaluation (pretest), secondly, there is often a daily evaluation (formative), and the third is what the lecturer usually does, namely the evaluation of volume increase (summative)." 41

Based on the description of the interview above, it can be ascertained that the lecturers who manage the implementation of the Safinda method in learning the translation of al-Quran at IAIN Fattahul Muluk Papua, namely the lecturers always give evaluations, for example, the initial evaluation (pretest) as the first step in implementing the method application program. Safinda in learning the translation of al-Quran The goal is to find out the students' initial abilities regarding the subject in question properly and correctly based on their meaning.

Daily evaluation (formative) in the application of the Safinda method in learning the translation of al-Quran functions like data collection during the learning process, namely through students' reading of the Safinda material. In the results of observations, the day evaluation is carried out individually, the lecturers tashih the students' reading. Namely through students read by themselves and lecturers listening to them. If a student misreads, the lecturer gives a warning with a knock. Through this evaluation, lecturers can understand the progress and development of student abilities so that students can learn the next material. In this case, the lecturer has the role of "teacher centered".

Summative evaluation is a combination of formative evaluation (daily tests) after the lecturer mentions the students' reading and is considered to have met the criteria both in terms of makhraj, fluency; students can take the juz increment test.

Further interviews with lecturers at IAIN Fattahul Muluk Papua are as follows:

"Yes, the formal evaluation has not yet been carried out, but the evaluation is carried out after the end of the lesson in one meeting, for example the lesson that day was finished and then tested one by one the extent of the student's success." 42

More advanced in an interview explained that:

"In the evaluation, it is carried out at the next meeting from what was learned yesterday, deposited on the next day at the beginning of the teaching and learning process." $" 43$

From the above statements, it can be found here that the evaluation system for the implementation of the Safinda method in learning the translation of alQuran at IAIN Fattahul Muluk Papua is carried out by the circumstances that allow it to be evaluated. Because the learning strategies used individually in addition to classical, student learning achievement is measured from each individual.

The results of observations also show that evaluation activities in the application of the Safinda method in learning the translation of al-Quran at IAIN

\footnotetext{
${ }^{41}$ Mihrajuddin, Student from Safinda Method IAIN Fattahul Muluk Papua. Interview, Papua, 3Mei, 2019.

${ }^{42}$ A. Ubaidillah, Lecturer of Safinda Method IAIN Fattahul Muluk Papua. Interview, Papua, 10Mei, 2019

${ }^{43}$ A. Ubaidillah, Lecturer of Safinda Method IAIN Fattahul Muluk Papua. Interview, Papua, 10Mei, 2019., 2019.
} 
Fattahul Muluk Papua are carried out regularly, carry out good learning evaluations starting from the initial evaluation, evaluation during the learning process, and endsemester evaluation to measure with student and faculty success implementing learning.

Subsequent observations of learning evaluations are carried out at the end of each lesson, and at the end of the semester in the form of practical exams. At the end of the semester there is a practical exam, so this translation learning is tested on the practical exam.

Based on interviews and observations, it shows that the lecturer has carried out a psychological evaluation (assessment is always needed for every effort made), didactic basis (in addition to assessing student learning outcomes, also assessing the results of the lecturer's efforts as educators) and administrative basis (assessment data summarized in the book assessment) for easy identification.

Evaluation of learning outcomes is an activity or method shown to determine whether or not the learning objectives are achieved and the process of applying the Safinda method in learning the translation of al-Quran at IAIN Fattahul Muluk Papua. In this evaluation phase Ability lecturers are required to have an in determining the approach and ways to evaluate the preparation of evaluation tools, processing and use of evaluation results.

Learning evaluation is one component that has a very important role in a series of learning activities. Through evaluation, not only teachers can collect information about various weaknesses in learning as feedback for improvement.

\section{CONCLUSION}

Based on the explanation above, it can be concluded that the application of the Safinda method in learning the translation of al-Quran to students at IAIN Fattahul Muluk Papua is carried out by (a) paying attention to class management which includes classroom arrangement and student management before entering preliminary activities; (b) in the introductory activity, the lecturer starts learning effectively and pleasantly by providing motivation to students; (c) the core activities are carried out through reading activities, aural-oral activities, and memorizing activities are all carried out classically and individually, namely the lecturer reads word for word followed by students, lecturers and students read word for word, students read word for word, the lecturer interprets it, the students interpret all the verses that have been read together, the students read one by one, then the lecturer gives the opportunity to students who do not understand to ask questions, and finally the lecturer explains all the verses that have been studied together. 


\section{REFERENCE}

Abaza, Tamyiz PintarTarjamahQur'andan KitabKuningJakarta:TamyizPublising,2013.

Adnan, M.Anas,MemahamiAl-Qur'andenganMetodeManhaji Surabaya: Pendidikan dan Pengembangan al-Qur'an(PPQ),2008.

Arief, Armai, Pengantar Ilmu dan Metodologi Pendidikan Islam Jakarta: Ciputat Press, 2002

Arif S. Sadiman dkk, Media Pendidikan Jakarta: Grafindo Persada, 2006.

Kafrawi, Pembaharuan Sistem Pendidikan Pondok PesantrenJakarta: Cemara Indah, 1978.

SoilihinBunyaminAhmad,PanduanBelajardanMengajar8 JamBisaMenerjemahkanAlQur'anMetodeGranadaSistem4LangkahTangerangSelat an: GranadaInvestaIslami, 2014.

\section{Interview Sources}

A. Ubaidillah, Lecturer of Safinda Method IAIN Fattahul Muluk Papua. Interview, Papua, 8 Maret, 2019.

M. Fikram S, Student of Safinda Method IAIN Fattahul Muluk Papua. Interview, Papua, 22 Maret, 2019.

Muhammad Tamsil, Student of Safinda Method IAIN Fattahul Muluk Papua. Interview, Papua, 22 Maret, 2019.

Hendriyanto, Student of Safinda Method IAIN Fattahul Muluk Papua. Interview, Papua, 22 Maret, 2019.

Muhammad Arfah, Student of Safinda Method IAIN Fattahul Muluk Papua. Interview, Papua, 22 Maret, 2019.

Fadel Anshori Mulihat, Student of Safinda Method IAIN Fattahul Muluk Papua. Interview, Papua, 22 Maret, 2019.

Khaedar Yunus, Student of Safinda Method IAIN Fattahul Muluk Papua. Interview, Papua, 5 April, 2019.

Irham Bayu, Student of Safinda Method IAIN Fattahul Muluk Papua. Interview, Papua, 19 April, 2019.

Amrul Muttaqin, Student of Safinda Method IAIN Fattahul Muluk Papua. Interview, Papua, 19 April, 2019.

Mihrajuddin, Student of Safinda Method IAIN Fattahul Muluk Papua. Interview, Papua, 3 Mei, 2019.

http://rikeu2000.wordpress.com,/tikror/ 1 April 2018 